\title{
Tingkat Kebugaran Jasmani Siswa SMP Negeri se-Kecamatan Bosar Maligas Kabupaten Simalungun Provinsi Sumatera Utara
}

\author{
Nurul Winda S Purba ${ }^{a}$, Sabaruddin Yunis Bangun ${ }^{b}$ \\ $a, b$ Prodi PJKR Universitas Negeri Medan, Sumatera Utara, Indonesia
}

*Corresponding author: unisbgn@ unimed.ac.id

\section{A R T I CLE INFO}

Article history:

Received 20 Maret 2019

Received in revised form 12 April

2019

Accepted 22 April 2019

Keywords:

Middle School Student Physical

Fitness

\begin{abstract}
A B S T R A C T
This research is motivated by the absence of data showing the level of physical fitness of state junior high school students and there has never been a test to measure the level of physical fitness of students of the State Junior High School in Bosar Maligas District, Simalungun Regency. This study aims to determine the level of physical fitness of students of the State Middle School in Bosar Maligas District, Simalungun Regency. This research is quantitative descriptive. Data collection techniques used are tests and measurements. The population in this study were all students of the State Middle School of Bosar Maligas District with a total of 646 students. The sample in this study were students of the State Junior High School of Bosar Maligas District with a total of 120 students taken $20 \%$ of the total population. The instrument used in this study was by testing the multistage fitness test run test. The data analysis technique used is percentage descriptive analysis. Classified research data shows that the level of physical fitness of students who are in a very poor classification is 109 students $(90.83 \%)$, 8 students $(6.67 \%)$ classification is lacking, 3 students $(2.5 \%)$ are quite good categories, and 0 students $(0 \%)$ classified as good, very good or special. It can be concluded that the level of physical fitness of the students of the State Junior High School in the Bosar Maligas District of Simalungun Regency is in the very less category.
\end{abstract}

\section{Pendahuluan}

Praktek pendidikan jasmani yang baik tentu akan menguntungkan banyak pihak, utamanya bagi peserta didik. Kondisi fisik atau tubuh mereka akan selalu sehat dan bugar. Harapannya, mereka akan meraih prestasi dan mampu menjaga kondisi tubuhnya tetap sehat dan bugar dimanapun dan kapanpun. Hal lain yang dapat dicapai adalah pembentukkan karakter dan kepribadian peserta didik melalui pendidikan jasmani dapat diwujudkan secara maksimal dan optimal.

Rosdiani (2012), pendidikan jasmani adalah proses kependidikan yang memiliki tujuan untuk mengembangkan penampilan manusia melalui media aktivitas jasmani yang terpilih untuk mencapai tujuan pendidikan. Peserta didik akan memperoleh berbagai ungkapan yang erat kaitannya dengan kesan pribadi yang menyenangkan serta berbagai ungkapan yang kreatif dan inovatif, terampil, memiliki kebugaran jasmani kebiasaan hidup sehat dan memiliki pengetahuan serta pemahaman terhadap gerak manusia.

Kebugaran dan kesehatan akan dicapai melalui program pendidikan jasmani yang terencana, teratur dan berkesinambungan. Program olahraga antar sekolah biasanya melahirkan semangat bersekolah. Tetapi hal itu tidak diketahui manakala spirit tersebut memberikan kontribusi terhadap prestasi belajar siswa.Aktivitas sekolah dapat digunakan untuk wahana pengalaman, tetapi olahraga memberi siswa aktivitas sosial yang unik yang dapat menjadikan sekolah menjadi tempat yang menarik.

Wiarto (2013), kebugaran jasmani adalah kesanggupan dan kemampuan tubuh untuk 
melakukan penyesuaian (adaptasi) terhadap pembebasan fisik yang diberikan kepadanya tanpa menimbulkan kelelahan yang berlebihan.

Salah satu unsur kebugaran jasmani adalah daya tahan kardiovaskuler yang dalam hal ini adalah volume oksigen maksimum atau VO2 Max.Kata "VO2 Max" diartikan sebagai kemampuan organ pernafasan manusia untuk menghirup oksigen sebanyak-banyaknya pada saat latihan.

Diketahui beberapa hal yang dilakukan oleh para siswa tergolong olahraga aerobik atau dalam hal lain sangat membutuhkan oksigen. Jadi bila kita ingin memiliki daya tahan aerobic yang baik maka kita juga harus memiliki VO2 Max yang baik untuk menampung oksigen sebanyak mungkin dan mendistribusikannya ke seluruh tubuh.

Berdasarkan uraian di atas terutama yang ada di sekolah, maka penelitian ini diadakan di SMP Negeri Sekecamatan Bosar Maligas, Kabupaten Simalungun. Masih banyaknya siswa yang merasa kelelahan ketika melakukan kegiatan dalam pembelajaran penjas, siswa yang merasa lelah pun akan merasa malas untuk mengikuti jam pembelajaran selanjutnya, dan akan menyebabkan menurunnya tingkat prestasi siswa dalam belajar. Hal tersebut didukung oleh hasil observasi dari peneliti yang melihat banyaknya siswa yang masuk ruang Usaha Kesehatan Sekolah (UKS). Sebanyak 42 orang siswa $(6,5 \%)$ di SMP Negeri Sekecamatan Bosar Maligas yang masuk ruang UKS pada 3 bulan terakhir, 20 orang siswa (12\%) dari keseluruhan siswa SMP Negeri 1 Bosar maligas dan 22 orang siswa (14\%) dari keseluruhan siswa SMP Negeri 2 Bosar Maligas. Dengan demikian pendidikan jasmani yang efektif mampu merangsang kemampuan berpikir dan daya analisis siswa ketika terlibat dalam kegiatankegiatan fisiknya.

Pola-pola permainan yang memerlukan tugas-tugas tertentu akan menekankan pentingnya kemampuan nalar siswa dalam hal membuat keputusan. Bagi peserta didik, kebugaran jasmani dapat meningkatkan prestasi belajar karena dengan kebugaran jasmani yang baik, mereka akan lebih siap menerima pelajaran dan akan menjadi generasi-generasi yang sehat dan bugar. Tingkat kebugaran jasmani peserta didik perlu diukur sebagai data kondisi kebugaran peserta didik. Berdasarkan gambaran tingkat kebugaran maka dapat dilakukan upaya-upaya peningkatan yang terarah dan efektif.

Pengukuran kebugaran jasmani peserta didik dapat dilakukan dengan perangkat Tes
Kebugaran Jasmani yaitu Multistage Fitness Test (MFT). Alasan penulis menggunakan Multistage Fitness Test (MFT) adalah pelaksanaan tes yang lebih praktis karena keterbatasan tempat pengambilan tes. Adapun untuk memperoleh data yang diinginkan untuk menunjang judul yang telah ditetapkan, peneliti menggunakan metode survey. Penelitian survey merupakan salah satu metode terbaik yang tersedia bagi para peneliti sosial yang tertarik untuk mengumpulan data guna menjelaskan suatu populasi yang terlalu besar untuk diamati secara langsung.

Hasil observasi dengan guru pendidikan jasamani di SMP Negeri Sekecamatan Bosar Maligas, Kabupaten Simalungun, diketahui bahwa di sekolah tersebut belum pernah diadakan tes kebugaran jasmani. Untuk mengetahui tingkat kebugaran jasmani siswa apakah telah memenuhi standar apa belum, maka perlu diadakan tes untuk mengetahui tingkat kebugaran jasmani siswa, yaitu dengan menggunakan Multistage Fitness Test (MFT).

Pendidikan jasmani merupakan bagian integral dari pendidikan secara keseluruhan, bertujuan untuk mengembangkan aspek kebugaran jasmani, keterampilan gerak, keterampilan berpikir kritis, keterampilan sosial, penalaran, stabilitas emosional, tindakan moral, aspek pola hidup sehat, dan pengenalan lingkungan hidup bersih melalui aktivitas jasmani, olahraga, dan kesehatan terpilih yang direncanakan secara sistematis dalam rangka mencapai tujuan pendidikan nasional.

Permendiknas No. 22 Tahun 2006 menyatakan bahwa, Pendidikan jasmani, olahraga dan kesehatan (Penjasorkes) merupakan bagian dari integral dari pendidikan secara keseluruhan, bertujuan untuk mengembangkan aspek kebugaran jasmani, keterampilan gerak, keterampilan berfikir kritis, keterampilan sosial, penalaran stabilitas emosional, tindakan moral, aspek pola hidup sehat dan pengenalan lingkungan bersih melalui aktivitas jasmani, olahraga dan kesehatan terpilih yang direncanakan secara sistematis dalam rangka mencapai tujuan pendidikan nasional.

Pendidikan jasmani yaitu: (1) Memenuhi kebutuhan anak akan gerak (2) Mengenalkan anak pada lingkungan dan potensi dirinya (3) Menanamkan dasar-dasar keterampilan yang berguna (4) Menyalurkan energi yang berlebihan (5) Merupakan proses pendidikan secara serempak baik fisik, mental maupun emosional. Giriwijoyo (2002) mengungkapkan, kebugaran jasmani adalah keadaan kemampuan jasmani yang 
dapat menyesuaikan fungsi alat alat tubuhnya terhadap tugas jasmani tertentu atau terhadap keadaan lingkungan yang harus diatasi dengan cara yang efisien, tanpa kelelahan yang berlebihan dan telah pulih sempurna sebelum datang tugas yang sama pada esok harinya

Secara umum yang dimaksud kebugaran adalah kebugaran fisik, yakni kemampuan seseorang untuk dapat melakukan kerja seharihari secara efisien tanpa timbul kelelahan yang berlebihan sehingga masih dapat menikmati waktu luangnya.

Nurhasan (2008), fungsi kebugaran jasmani dalam kaitannya dengan aktivitas belajar, dapat dicermati melalui hasil tes kebugaran jasmani sehingga dapat diketahui mengenai:

- Kemampuan fisik siswa

- Status kondisi keadaan siswa

- Melihat perkembangan fisik siswa

- Sebagai bahan masukan dalam memberikan nilai penjas

Sebagai bahan untuk memberikan bimbingan kepada para siswa dalam upaya meningkatkan kebugarannya Kondisi fisik yang bugar akan memberikan pengaruh yang positif terhadap aktivitas fisik dan kualitas kinerja.

Peneliti menyimpulkan tentang manfaat yang diperoleh jika memiliki kebugaran jasmani yang baik adalah memberikan kemudahan bagi seseorang atau siswa dalam melaksanakaan tugas sehari-hari tanpa mengalami kelelahan yang berarti dan akan menghindari seseorang dari berbagai macam penyakit baik ringan maupun berat serta meningkatkan kemampuan belajar.

Wahjoedi (2001) kebugaran jasmani dapat diklasifikasikan menjadi dua, yaitu: kebugaran jasmani yang berhubungan dengan kesehatan dan kebugaran jasmani yang berhubungan dengan keterampilan gerak. Komponen kebugaran jasmani yang berhubungan dengan kesehatan (health related fitness) yaitu: daya tahan jantungparu,daya tahan otot, kekuatan otot, kelentukan, komposisi tubuh. Komponen kebugaran jasmani yang berhubungan dengan keterampilan (motorskill related fitness) yaitu: kecepatan, kecepatan reaksi, daya ledak, kelincahan, keseimbangan, ketepatan, koordinas

Terdapat 5 komponen kesegaran jasmani yang berhubungan dengan kesehatan yaitu: Daya tahan kardiorespirasi, kekuatan otot, daya tahan otot, kelenturan, komposisi tubuh.

Lari multitahap (Multistage fitness test) Widiastuti (2017). MFT atau Bleep Test adalah tes yang digunakan untuk mengetahui tingkat kebugaran jasmani seseorang. Tes MFT dapat dilakukan terhadap beberapa orang sekaligus asalkan tester dapat mencatat dengan tepat dan cermat setiap tahapan tes dan dapat menghentikannya dengan tepat sesuai ketentuan MFT. Tes ini bukan merupakan alat ukur yang canggih, tetapi menghasilkan suatu paduan daya tahan yang sebagian besar ditentukan oleh seberapa besar tingkat efisiensi fungsi jantung dan paru-paru. Hal ini ditunjukkan dengan baik melalui pengukuran ambilan oksigen maksimum Tujuannya adalah mengetahui tingkat kebugaran jasmani terutama untuk mengukur daya tahan jantung-paru.

\section{Metode Penelitian}

Penelitian ini dilaksanakan di SMP Negeri Sekecamatan Bosar Maligas. Populasi yang dimaksud dalam penelitian ini adalah Siswa/i SMP Negeri Sekecamatan Bosar Maligas Kabupaten Simalungun yang berjumlah 646 siswa. Pedoman bahwa apabila populasi di bawah 100 dapat dipergunakan sampel sebesar 50\% dari populasi, dan jika populasi berada di antara 100 sampai 1000 maka dipergunakan sampel sebesar $15 \%$ - 50\% dari jumlah populasi. sampel dalam penelitian ini yaitu siswa SMP Negeri Sekecamatan Bosar Maligas dengan jumlah 120 siswa, jumlah ini diambil $20 \%$ dari jumlah populasi 646 siswa $(20 \%$ x $646=129$ disesuaikan menjadi 120).

Metode penelitian ini adalah survey dengan pendekatan kuantitatif, penelitian ini menggunakan teknik tes dan pengukuran. Tes adalah sebuah instrumen atau alat yang digunakan untuk mendapatkan informasi mengenai individu atau objek, sedangkan pengukuran adalah mengumpulkan informasi, Ali Maksum (2012). Tes yang dilakukan untuk mengetahui tingkat kebugaran siswa/i di SMP Negeri Sekecamatan Bosar Maligas Kabupaten Simalungun ini menggunakan tes lari multi tahap (multistage fitness test) yaitu tes lari bolak-balik 20 meter.

Instrumen adalah alat ukur yang digunakan untuk mengumpulkan data dalam penelitian, Ali Maksum (2012). Instrumen atau alat yang digunakan dalam penelitian ini adalah tes lari multi tahap (multistage fitness test) yaitu tes lari bolak-balik 20 meter dan survey. Tes ini memiliki banyak kelebihan atau kemudahan diantaranya dapat dilaksanakan di lapangan yang tidak begitu luas, peserta tes lebih mudah dalam pengawasan, dan siswa dapat di tes bersama-sama atau secara berkelompok. 
Teknik pengumpulan data yang digunakan dalam penelitian ini adalah menggunakan tes. Tes adalah sebuah prosedur yang sistematis dan objektif untuk memperoleh data atau keterangan yang diinginkan dengan cara relatif tepat, Ali Maksum (2012). Tes yang digunakan dalam penelitian ini adalah Multistage Fitness Test. Data yang diperoleh kemudian dicocokkan dengan tabel prediksi VO2 Maks, lalu setelah diketahui prediksi VO2 Maks-nya, data dikonversikan ke dalam tabel norma pengklasifikasian lari multistage fitness test.

Berikut ini prosedur melakukan bleep test.

1. Ukurlah jarak 20 meter dan berikan tanda garis dengan menggunakan kapur.

2. Perintahkan peserta tes melakukan pemanasan secukupnya.

3. Start dilakukan dengan berdiri dan posisi kaki berada di belakang garis pada salah satu sisi. Dengan aba - aba "siap-ya" (sesuai dengan irama pada kaset), atlet lari sesuai dengan irama kaset menuju ke sisi yang berlawanan.

4. Peserta tes harus berusaha sampai ke sisi berlawanan bertepatan dengan bunyi "tut" yang pertama dari kaset.

5. Akhir setiap lari ditandai dengan sinyal "tut" tunggal, sedangkan akhir dari setiap level ditandai dengan sinyal "tut" tiga kali.

6. Bila tanda bunyi "tut" berlum terdengar saat atlet sampai pada sisi berlawanan (atlet lebih cepat dari tempo), maka untuk lari balik harus menunggu tanda bunyi "tut". Sebaliknya, jika atlet belum sampai pada sisi berlawanan namun sinyal bunyi "tut" sudah terdengar (atlet lebih lambat dari pada tempo), maka atlet harus meningkatkan kecepatannya.

7. Bila dua kali bunyi "tut" berurutan atlet tidak mampu mengikuti irama waktu lari berarti atlet tersebut sudah mencapai batas maksma dan tes dianggap sudah berakhir.

8. Hasil tes yang berupa level dan balikan kemudian dicocokan dengan norma tes yang berupa prediksi VO2max.

Teknik analisis data yang digunakan dalam penelitian ini adalah analisis deskriptif kuantitatif dengan persentase. Statistik deskriptif adalah bagian dari statistik yang membahas mengenai penyusunan data ke dalam daftar, grafik atau bentuk lain yang tidak dimaksudkan untuk pengujian hipotesis atau penarikan kesimpulan Maksum Ali (2012). Suharsimi, Arikunto (2003) rumus yang digunakan untuk mencari persentase adalah sebagai berikut :
$\mathrm{P}=\frac{F}{N} \times 100 \%$
P: Persentase yang dicari
F: Frekuensi
$\mathrm{N}$ : Jumlah responden

\section{Hasil}

Data hasil penelitian tingkat kebugaran siswa SMP Negeri Sekecamatan Bosar Maligas Kabupaten Simalungun, yang diperoleh setelah melaksanakan tes lari multistage fitness test menghasilkan data berupa level dan shuttle yang berhasil dicapai siswa. Data tersebut kemudian dikonversikan ke dalam tabel prediksi VO2 Maks yang telah tersedia untuk mengetahui berapa skor VO2 Maks yang berhasil dicapai siswa. Kemudian data skor VO2 Maks yang berhasil dicapai siswa tersebut diklasifikasikan ke dalam norma pengklasifikasian multistage fitness test. Hasil pengklasifikasian tersebut dapat dilihat pada tabel berikut:

Tabel 1. Distribusi Frekuensi Klasifikasi Tingkat Kebugaran Siswa SMP Negeri Sekecamatan Bosar Maligas Kabupaten Simalungun Prov. Sumut

\begin{tabular}{cccc}
\hline \multirow{2}{*}{$\begin{array}{c}\text { Interval } \\
\text { Skor }\end{array}$} & Klasifikasi & \multicolumn{2}{c}{ Frekuensi } \\
\cline { 3 - 4 } & & Absolut & Persentase (\%) \\
\hline $\mathbf{3 5}$ & Sangat Kurang & 109 & 90,83 \\
\hline $\mathbf{3 5 - 3 7}$ & Kurang & 8 & 6,67 \\
\hline $\mathbf{3 8 - 4 4}$ & Cukup Baik & 3 & 2,5 \\
\hline $\mathbf{4 5 - 5 0}$ & Baik & 0 & 0 \\
\hline $\mathbf{5 1 - 5 5}$ & Baik Sekali & 0 & 0 \\
\hline$>\mathbf{5 5}$ & Istimewa & 0 & 0 \\
\hline & Jumlah & 120 & 100 \\
\hline
\end{tabular}

Tabel 1 distribusi frekuensi klasifikasi tingkat kebugaran siswa SMP Negeri Sekecamatan Bosar Maligas Kabupaten Simalungun di atas dapat dilihat bahwa dari tes yang telah dilakukan oleh 120 siswa menunjukkan hasil sebagai berikut: siswa yang tingkat kebugaran berada pada kategori sangat kurang. Sejumlah 109 siswa atau dengan persentase sebesar $(90,83 \%)$, kategori kurang sejumlah 8 siswa $(6,67 \%)$, kategori cukup baik sejumlah 3 siswa (2,5\%), dan tidak ada siswa $(0 \%)$ yang tingkat kebugarannya berada pada kategori baik, baik sekali maupun istimewa. Histogram distribusi frekuensi klasifikasi tingkat kebugaran siswa SMP Negeri Sekecamatan Bosar Maligas Kabupaten Simalungun Prov. Sumatera Utara tersebut dapat disajikan seperti gambar $1 \mathrm{di}$ bawah ini: 


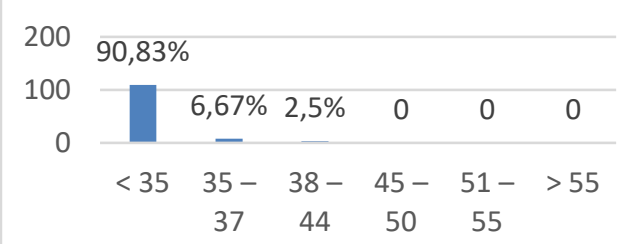

Gambar 1. Histogram Distribusi Frekuensi Klasifikasi Tingkat Kebugaran Jasmani Siswa SMP Negeri Sekecamatan Bosar Maligas Kabupaten Simalungun Provinsi Sumatera Utara

Distribusi frekuensi klasifikasi tingkat kebugaran jasmani siswa putra dan dilanjutkan dengan siswi putri SMP Negeri Sekecamatan Bosar Maligas Kabupaten Simalungun dapat dilihat seperti tabel 2 di bawah ini:

Tabel 2. Distribusi Frekuensi Klasifikasi Tingkat Kesegaran Kardiorespirasi Siswa Putra SMP Negeri Sekecamatan Bosar Maligas Kabupaten Simalungun Provinsi Sumatera Utara

\begin{tabular}{|c|c|c|c|}
\hline \multirow[t]{2}{*}{ Interval Skor } & \multirow[t]{2}{*}{ Klasifikasi } & \multicolumn{2}{|c|}{ Frekuensi } \\
\hline & & Absolut & Persentase (\%) \\
\hline$<35$ & Sangat Kurang & 59 & 98,33 \\
\hline $35-37$ & Kurang & 1 & 1,67 \\
\hline $38-44$ & Cukup Baik & 0 & 0 \\
\hline $45-50$ & Baik & 0 & 0 \\
\hline $51-55$ & Baik Sekali & 0 & 0 \\
\hline$>55$ & Istimewa & 0 & 0 \\
\hline \multicolumn{2}{|c|}{ Jumlah } & 60 & 100 \\
\hline
\end{tabular}

Distribusi frekuensi klasifikasi tingkat kebugaran siswa putra SMP Negeri Sekecamatan Bosar Maligas Kabupaten Simalungun di atas dapat dilihat bahwa dari 60 siswa putra yang mengikuti tes lari multistage fitness test menunjukkan siswa putra yang tingkat kebugarannya berada pada kategori sangat kurang sejumlah 59 siswa $(98,33 \%)$, 1 siswa $(1,67 \%)$ yang tingkat kebugarannya pada kategori kurang, dan 0 siswa $(0 \%)$ yang tingkat kebugarannya berada pada kategori baik, baik sekali maupun istimewa. Daftar distribusi frekuensi klasifikasi tingkat kebugaran siswa putra SMP Negeri Sekecamatan Bosar Maligas Kabupaten Simalungun tersebut kemudian disajikan dalam bentuk histogram yang dapat dilihat seperti pada gambar di bawah ini:

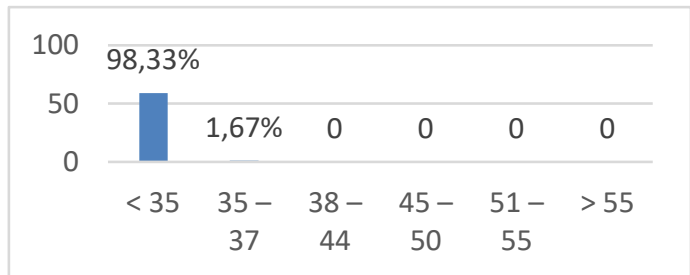

Gambar 2. Histogram Distribusi Frekuensi Klasifkasi Tingkat Kebugaran Siswa Putra SMP Negeri Sekecamatan Bosar Maligas Kabupaten Simalungun Provinsi Sumatera Utara
Tabel 3. Distribusi Frekuensi Klasifikasi Tingkat Kebugaran Siswi Putri SMP Negeri Sekecamatan Bosar Maligas Kabupaten Simalungun Provinsi Sumatera Utara

\begin{tabular}{|c|c|c|c|}
\hline \multirow[t]{2}{*}{ Interval Skor } & \multirow[t]{2}{*}{ Klasifikasi } & \multicolumn{2}{|c|}{ Frekuensi } \\
\hline & & Absolut & Persentase (\%) \\
\hline$<35$ & Sangat Kurang & 50 & 83,33 \\
\hline $35-37$ & Kurang & 7 & 11,67 \\
\hline $38-44$ & Cukup Baik & 3 & 5 \\
\hline $45-50$ & Baik & 0 & 0 \\
\hline $51-55$ & Baik Sekali & 0 & 0 \\
\hline$>55$ & Istimewa & 0 & 0 \\
\hline \multicolumn{2}{|c|}{ Jumlah } & 60 & 100 \\
\hline
\end{tabular}

Distribusi frekuensi klasifikasi tingkat kebugaran siswi putri SMP Negeri Sekecamatan Bosar Maligas Kabupaten Simalungun di atas dapat dilihat bahwa dari 60 siswi putri yang mengikuti tes lari multistage fitness test menunjukkan siswi putri yang tingkat kebugarannya berada pada kategori sangat kurang sejumlah 50 siswi dan jika dipersantase sebesar (83,33\%), 7 siswi (11,67\%) tingkat kebugarannya berada pada kategori kurang, 3 siswi (5\%) tingkat kebugarannya berada kategori cukup baik, dan 0 siswa (0\%) yang tingkat kebugarannya berada pada kategori baik, baik sekali, maupun istimewa.

Daftar distribusi frekuensi klasifikasi tingkat kebugaran jasmani siswi putri SMP Negeri Sekecamatan Bosar Maligas Kabupaten Simalungun tersebut kemudian disajikan dalam bentuk histogram yang dapat dilihat seperti pada gambar di bawah ini:

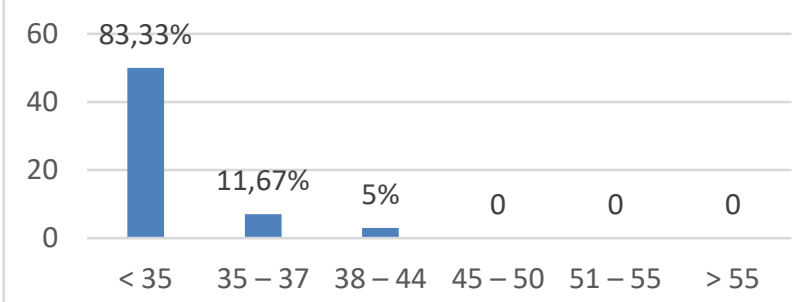

Gambar 3. Histogram Distribusi Frekuensi Klasifikasi Tingkat Kesegaran Kardiorespirasi Siswi Putri SMP Negeri Sekecamatan Bosar Maligas Kabupaten Simalungun Provinsi Sumatera Utara

Hasil penelitian ini menunjukkan bahwa tingkat kebugaran antara satu siswa dengan siswa lainnya berbeda-beda. Data hasil capaian siswa yang telah melakukan tes lari multistage fitness test kemudian dikonversikan menurut norma pengklasifikasian tes lari multistage fitness tes. 


\section{Simpulan dan Rekomendasi}

Data hasil penelitian tingkat kebugaran yang diperoleh dengan pengukuran menggunakan tes lari multistage fitness test yang diikuti oleh 120 siswa SMP Negeri Sekecamatan Bosar Maligas Kabupaten Simalungun Provinsi Sumatera Utara, menunjukkan bahwa siswa yang tingkat kebugarannya berada pada kategori sangat kurang.

Jumlah 109 siswa dan jika dipersentase sebesar $(90,83 \%), 8$ siswa $(6,67 \%)$ berada pada kategori kurang, 3 siswa $(2,5 \%)$ berada pada kategori cukup baik, dan 0 siswa $(0 \%)$ yang tingkat kebugaran jasmaninya berada pada klasifikasi baik, baik sekali maupun istimewa. Kesimpulan dari tingkat kebugaran siswa SMP Negeri Sekecamatan Bosar Maligas Kabupaten Simalungun Provinsi Sumatera Utara yakni berada pada kategori sangat kurang karena mayoritas dari siswa yang diteliti berada pada kategori sangat kurang yaitu dengan persentase sebesar $90,83 \%$.

Siswa yang memiliki tingkat kebugaran jasmani yang kurang selalu mengalami hambatan dalam melakukan pekerjaan dan aktifitas seharihari dan aktifitas belajar, siswa akan mengalami hambatan baik dalam hal konsentrasi maupun dalam hal kemampuan berfikir. Untuk itu guru pendidikan jasmani harus memiliki kompetensi dalam memberikan pengajaran penjas, yaitu:

1. Memahami karakteristik anak didik.

2. Mampu membangkitkan dan memberi kesempatan anak didik untuk aktif dan kreatif dalam proses pembelajaran pendidikan jasmani dan mampu menumbuh kembangkan kemampuan motorik dan keterampilan motorik.

3. Mampu memberikan bimbingan dan mengembangkan potensi anak didik dalam proses pembelajaran untuk mencapai tujuan pendidikan jasmani.

4. Mampu merencanakan, melaksanakan, mengendalikan dan menilai serta mengkoreksi dalam proses pembelajaran pendidikan jasmani.

5. Memiliki pemahaman tentang unsur-unsur kondisi fisik.

6. Memiliki kemampuan untuk menciptakan, mengembangkan dan memanfaatkan lingkungan yang sehat dalam upaya mencapai tujuan pendidikan jasmani.

7. Memiliki pemahaman dan penguasaan kemampuan keterampilan motorik.

8. Memiliki kemampuan untuk menyalurkan hobinya dalam berolahraga.

9. Memahami pengetahuan pendidikan jasmani sebagai bidang studi.

\section{Daftar Pustaka}

Van der Geer, J., Hanraads, J. A. J., \& Lupton, R. A. (2000). The art of writing a scientific article. Journal of Science Communication, $163,51-59$.

Strunk, W., Jr., \& White, E. B. (1979). The elements of style (3rd ed.). New York: MacMillan.

Mettam, G. R., \& Adams, L. B. (1999). How to prepare an electronic version of your article. In B. S. Jones \& R. Z. Smith (Eds.), Introduction to the electronic age (pp. 281304). New York: E-Publishing Inc.

Fachinger, J., den Exter, M., Grambow, B., Holgerson, S., Landesmann, C., Titov, M., et al. (2004). Behavior of spent HTR fuel elements in aquatic phases of repository host rock formations, 2nd International Topical Meeting on High Temperature Reactor Technology. Beijing, China, paper \#B08.

Fachinger, J. (2006). Behavior of HTR fuel elements in aquatic phases of repository host rock formations. Nuclear Engineering \& Design, 236. 